\author{
EVS24 \\ Stavanger, Norway, May 13-16, 2009
}

\title{
Internal resistance of cells of lithium battery modules with FreedomCAR model
}

\author{
H. Culcu ${ }^{a}$, B. Verbrugge ${ }^{b}$, N. Omar ${ }^{a}$, P. Van Den Bossche ${ }^{b}$, J. Van Mierlo ${ }^{a}$ \\ ${ }^{\text {a }}$ Vrije Universiteit Brussel, IR-ETEC, Pleinlaan 2, B-1050 Brussels, Belgium \\ ${ }^{\mathrm{b}}$ Erasmushogeschool Brussel, IWT, Nijverheidskaai 170, B-1070 Brussels, Belgium \\ hasan.culcu@vub.ac.be,bavo.verbrugge@docent.ehb.be,noshomar@vub.ac.be, \\ peter.van.den.bossche@docent.ehb.be,jvmierlo@vub.ac.be
}

\begin{abstract}
Internal resistance is usually calculated by EIS (Electrochemical Impedance Spectroscopy) method, which gives unrealistic low internal resistance values. In this paper internal resistance will be calculated from the voltage drop with FreedomCAR method where the validation of the results is much better (99\%) than EIS method[1][12]. Batteries are often tested per cell. But in most cases more than one single cell is needed for an application and the characteristics of a module of cells is not the same. In other cases the whole module is examined as one big cell, without looking on the individual cells. But the weakest cell affects the performance of the whole module. This research goes deeper than the module approach on batteries: the behavior of individual cells is examined while they are working together in a module. The battery model consists in most researches of an ideal voltage source and a simple internal resistance[2]. In this work the advanced FreedomCAR battery model, created by Idaho National Laboratories (USA), is used: the cell is represented by an ideal voltage source with two internal resistances and two capacitors. Usually batteries are tested with very low constant currents (till 5\% of the nominal current value) to show a high capacity value to the customer, while the customer needs the characteristics of the battery in real conditions. Here the parameters are calculated by testing the battery packets in high pulse conditions. The matching between the predicted and the measured voltage is proportional with the quality of the model. This was $99 \%(+-0.9 \%)$ in the tests. This means that the model is very close to the reality. Three types of Lithium-ion battery packets with 6-7 cells were tested.
\end{abstract}

Keywords: lithium battery, internal resistance, FreedomCar model, cell parameters

$\begin{array}{ll}\text { ABBREVIATIONS } \\ \text { OCV } & \text { Ideal battery voltage }[\mathrm{V}] \\ \mathrm{C} & \text { Capacity [Ah] } \\ \mathrm{I}_{\mathrm{ch}, \max } & \text { Maximum charge current }[\mathrm{A}] \\ \mathrm{I}_{\mathrm{dch}} & \text { Discharge current }[\mathrm{A}] \\ \mathrm{I}_{\mathrm{L}} & \text { Battery load current }[\mathrm{A}] \\ \mathrm{I}_{\mathrm{P}} & \text { Current through polarization resistance }[\mathrm{A}] \\ \mathrm{OCV} & \text { Variation of OCV per exchanged capacity }[\mathrm{V} / \mathrm{As}] \\ \mathrm{R}_{\mathrm{i}} & \text { Internal resistance (general, total) }[\Omega]\left(=\mathrm{R}_{\mathrm{p}}+\mathrm{R}_{\mathrm{o}}\right)\end{array}$

$\mathrm{R}_{\mathrm{o}} \quad$ Battery internal "ohmic" resistance $[\Omega]$

$\mathrm{R}_{\mathrm{p}} \quad$ Battery internal "polarization" resistance [ $\left.\Omega\right]$

SOC State of Charge [As]

$\mathrm{V} \quad$ Voltage [V]

$\mathrm{V}_{\mathrm{cc}} \quad$ Closed circuit voltage

$\mathrm{V}_{\mathrm{L}} \quad$ Battery terminal voltage [V]

$\mathrm{V}_{\mathrm{oc}} \quad$ Open circuit voltage

$\tau \quad$ Polarization constant $=\mathrm{R}_{\mathrm{p}} * \mathrm{C}[\mathrm{s}]$ 


\section{Introduction}

The evolution of the cell parameters are determined as a function of the number of cycles and as a function of SOC. The parameters are calculated at the package level and at the cell level. Three types of lithium batteries are listed in Table 1. Six (seven for type 2) cells are placed in series.

\begin{tabular}{|c|c|c|c|}
\hline & Type 1 & Type 2 & Type 3 \\
\hline V & $\begin{array}{l}3.3 \mathrm{~V} \\
(2 \ldots 3.6 \mathrm{~V})\end{array}$ & $\begin{array}{l}3.2 \mathrm{~V} \\
(2.5 \ldots 3.65 \mathrm{~V})\end{array}$ & $\begin{array}{l}3.2 \mathrm{~V} \\
(2.1 \ldots 3.65 \mathrm{~V})\end{array}$ \\
\hline $\mathrm{C}$ & $2.3 \mathrm{Ah}$ & $3.2 \mathrm{Ah}$ & $10 \mathrm{Ah}$ \\
\hline \multirow{2}{*}{$\begin{array}{l}\mathrm{I}_{\mathrm{dch}}, \\
\max \end{array}$} & 70A cont. & 12A cont. & $120 \mathrm{~A}$ cont. \\
\hline & $120 \mathrm{~A} \mathrm{10s}$ & $28 \mathrm{~A} 30 \mathrm{~s}$ & 140A 18s \\
\hline$I_{c h, \text { max }}$ & $10 \mathrm{~A}$ to $3.6 \mathrm{~V}$ & $3.2 \mathrm{~A}$ to $4.1 \mathrm{~V}$ & $30 \mathrm{~A}$ \\
\hline \multirow{3}{*}{$\mathrm{R}_{\mathrm{i}}$} & $\begin{array}{l}8 \mathrm{~m} \Omega(1 \mathrm{kHz} \\
\mathrm{AC})\end{array}$ & $\begin{array}{l}<19 \mathrm{~m} \Omega \quad(1 \mathrm{kHz} \\
\mathrm{AC})\end{array}$ & $6 \mathrm{~m} \Omega$ \\
\hline & $\begin{array}{l}10 \mathrm{~m} \Omega \quad(10 \mathrm{~A} \\
1 \mathrm{~s} \mathrm{DC})\end{array}$ & & \\
\hline & $>1000$ cycles & & $>1000$ cycles \\
\hline \multirow[t]{2}{*}{$M$} & $70 \mathrm{~g}$ & $82 \mathrm{~g}$ & $400 \mathrm{~g}$ \\
\hline & $66-26-26 \mathrm{~mm}$ & $65-26-26 \mathrm{~mm}$ & $\begin{array}{l}138-40-40 \\
\mathrm{~mm}\end{array}$ \\
\hline
\end{tabular}

Table 1: Datasheet of the batteries

\section{Battery model}

The FreedomCAR linear battery model is shown on Fig. 1. A high pulsing current $\mathrm{I}_{\mathrm{L}}$ (Fig. 2), has to be loaded according to this model [3][4][5].

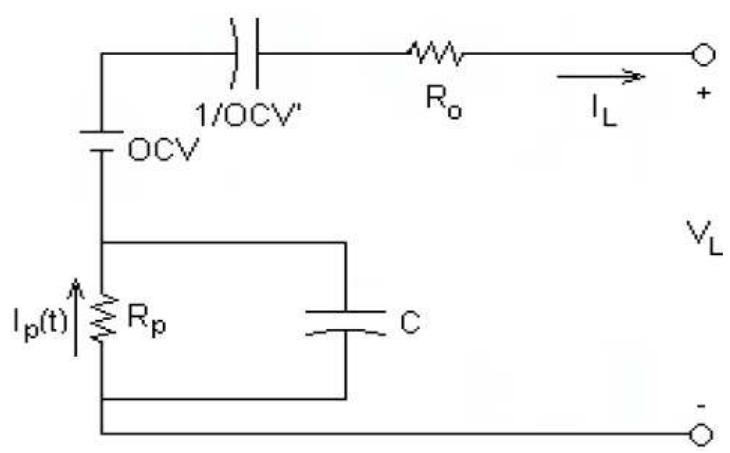

Fig. 1: FreedomCAR model

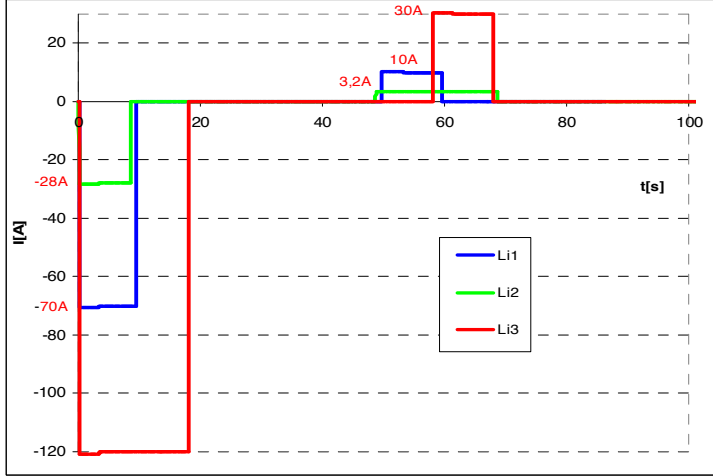

Fig. 2: The loaded FreedomCAR current profile $\mathrm{I}_{\mathrm{L}}$ for the three battery types

Considering the model on Fig. 1, one can write:

$$
\begin{gathered}
V_{L}=O C V-O C V^{\prime}\left[\int I_{L} d t\right]-R_{O}\left[I_{L}\right]-R_{P}\left[I_{P}\right] \\
\frac{d I_{p}}{d t}=\frac{I_{L}-I_{p}}{T} \text { or } \frac{d I_{p}}{I_{L}-I_{p}}=\frac{d t}{T}
\end{gathered}
$$

After discretisation of equation (1), the next simplified equation can be written:

$$
[Y]=b+m_{1}\left[X_{1}\right]+m_{2}\left[X_{2}\right]+m_{3}\left[X_{3}\right]
$$

In (1):

- $\quad \mathrm{V}_{\mathrm{L}}, \mathrm{I}_{\mathrm{L}}$ and $\mathrm{t}$ are measured

- $\quad \mathrm{I}_{\mathrm{p}}$ comes from (4)

- OCV, OCV', $\mathrm{R}_{\mathrm{o}}$ and $\mathrm{Rp}$ are calculated by linear regression method

Discretising and solving the differential equation (2), with the starting condition $\mathrm{I}_{\mathrm{p}}(\mathrm{t}=0)=0$, gives for every sample i:

$I_{p, i}=\left\{1-\left[\frac{1-e^{\frac{-\Delta t}{\tau}}}{\frac{\Delta t}{\tau}}\right]\right\} \cdot I_{L, i}+\left\{\left[\frac{1-e^{\frac{-\Delta t}{\tau}}}{\frac{\Delta t}{\tau}}\right]-e^{\frac{-\Delta t}{\tau}}\right\} \cdot I_{L, i-1}$

$$
-\left\{e^{\frac{-\Delta t}{\tau}}\right\} \cdot I_{p, i-1}
$$

$\tau$ is chosen or calibrated in the model so that the fitting between the measured and estimated voltage (Fig. 3) would be optimal. The difference between the measured and the estimated voltage $\mathrm{V}_{\mathrm{L}}$ in [\%] (Fig. 3) is proportional with the quality of the model. This is around $99 \%$ in the tests. 


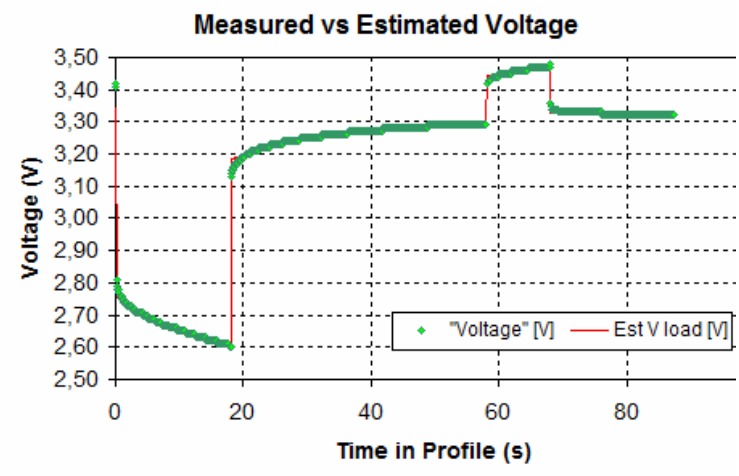

Fig. 3: Measured vs estimated voltage

\section{TEST RESULTS: Internal resistance}

\subsection{Internal Resistance}

There are 205 FreedomCar tests (Fig. 2) done on the three battery types, which corresponds to 685Ah. The temperature is kept constant at approximately $25{ }^{\circ} \mathrm{C}$ by a fan and is also measured. As mentioned in chapter 2 the voltages of the cells will be measured as well as the current and the temperature of one cell. This data is filled in in a spreadsheet, where OCV', $\mathrm{R}_{\mathrm{p}}, \mathrm{R}_{\mathrm{o}}$ and OCV will be calculated. $\tau$ is calibrated so that the matching between the measurements and model would be optimal.

The result is shown on Table 2 .

\begin{tabular}{|c|c|c|c|c|c|c|c|c|c|c|c|}
\hline $\mathrm{Ri}$ & $\mathrm{T}$ & SOC & \multicolumn{3}{|c|}{ type 1} & \multicolumn{3}{|c|}{ type 2} & \multicolumn{3}{|c|}{ type 3} \\
\hline \multicolumn{2}{|c|}{$[\mathrm{m} \Omega]\left[{ }^{\circ} \mathrm{C}\right]$} & [\%] & \multicolumn{3}{|c|}{$\min$ mean $\max$} & \multicolumn{3}{|c|}{$\min$ mean $\max$} & \multicolumn{3}{|c|}{ min mean $\max$} \\
\hline $\mathrm{Rp}$ & 25 & $100 \%$ & 1,8 & 5 & 7,8 & 5 & 7,5 & 10 & 2 & 1,8 & 1,9 \\
\hline $\mathrm{Rp}$ & 25 & $15 \%$ & 9 & 10 & 12 & 27 & 32 & 37 & 4 & 4,3 & 4,6 \\
\hline Ro & 25 & $100 \%$ & 8 & 12 & 15 & 23 & 25 & 28 & 4 & 5,1 & 5,8 \\
\hline \multirow{2}{*}{\multicolumn{2}{|c|}{ Ro $\mathrm{Ro}$}} & $15 \%$ & 12 & 13 & 14 & 19 & 22 & 25 & 7 & 7,1 & 7,5 \\
\hline & & $100 \%$ & 9,8 & 16 & 23 & 28 & 33 & 38 & 7 & 7,4 & 7,7 \\
\hline $\mathrm{Rp}-$ & & $15 \%$ & 21 & 23 & 25 & 46 & 54 & 62 & 12 & 12 & 12 \\
\hline \multicolumn{3}{|c|}{$R \_$_producer } & \multicolumn{3}{|c|}{10} & \multicolumn{3}{|c|}{19} & \multicolumn{3}{|c|}{6} \\
\hline \multicolumn{3}{|c|}{ \#f.car cycli } & \multicolumn{3}{|c|}{46} & \multicolumn{3}{|c|}{37} & \multicolumn{3}{|c|}{122} \\
\hline \multicolumn{3}{|c|}{ \#exchanged Cap. } & \multicolumn{3}{|c|}{84} & \multicolumn{3}{|c|}{27} & \multicolumn{3}{|c|}{574} \\
\hline
\end{tabular}

Table 2: Internal resistance at cell level; $\mathrm{T}=25^{\circ} \mathrm{C}$

\subsection{Influence of SOC}

The table shows that when the SOC decreases from 100 to $15 \%$ the total internal resistance $R_{i}$ $\left(=R_{p}+R_{o}\right)$ increases with $50-100 \%$, especially due to $R_{p}$. $\quad R_{p}$ has a more dynamic character in comparison with $\mathrm{R}_{\mathrm{o}}$ which stays nearly constant.

\subsection{Comparison with the datasheets}

The calculated resistance is $50-100 \%$ higher than the value measured by the producer. Type 3 has the lowest internal resistance and the value provided from the producer is much closer to the one which is calculated by FreedomCar model.

\subsection{Imbalance between the cells}

Type 3 has the lowest internal resistance imbalance between the cells. At full SOC the variation of $R_{i}$ between the cells was $0,7 \mathrm{~m} \Omega$. For type 1 and 2 it was 13 and $10 \mathrm{~m} \Omega$. That means a battery management system (to balance cells) is less needed in case of type 3 than in case of type 1 or 2 , which is an advantage of type 3 .

\subsection{Cell versus pack}

Consider a pack which is capable to deliver 10Ah at $24 \mathrm{~V}$ with only one type of cell by placing the right number of cells in parallel and/or in series, then the three types can be compared at package level (Table 3). The combination manner is written at the top of the columns. E.g. for type 18 cells are placed in series and form a group; there are 4 such groups placed in parallel. This is abbreviated as " $8 \mathrm{~s} 4 \mathrm{p}$ " in Table 3.8 cells are needed to get $24 \mathrm{~V}$ and 4 groups in parallel are needed to reech 10Ah. For type 23 parallel placed groups contain each 8 in series placed cells $(8 \mathrm{~s} 3 \mathrm{p})$. The same calculation is done for a pack of $120 \mathrm{~A}$ and $24 \mathrm{~V}$.

\begin{tabular}{|c|c|c|c|c|c|c|c|c|c|c|}
\hline \multicolumn{2}{|c|}{ Pack 24V 10Ah } & \multicolumn{3}{|c|}{$8 \mathrm{~s} 4 \mathrm{p}$} & \multicolumn{3}{|c|}{$8 \mathrm{~s} 3 \mathrm{p}$} & \multicolumn{3}{|c|}{$8 \mathrm{~s} 1 \mathrm{p}$} \\
\hline $\mathrm{Rp}+\mathrm{Ro}$ & $100 \%$ & 19,6 & 33 & 46 & 75 & 87 & 100 & 56 & 59 & 62 \\
\hline \multirow{2}{*}{\multicolumn{2}{|c|}{$\begin{array}{l}\mathrm{Rp}+\mathrm{Ro} \quad \sim 15 \% \\
R \text { producer }\end{array}$}} & 41 & 46 & 51 & 123 & 143 & 164 & 94 & 96 & 98 \\
\hline & & \multicolumn{3}{|c|}{20} & \multicolumn{3}{|c|}{51} & \multicolumn{3}{|c|}{48} \\
\hline
\end{tabular}

\begin{tabular}{|c|c|c|c|c|c|c|c|c|c|}
\hline \multicolumn{2}{|c|}{ Pack 24V 120A } & \multicolumn{3}{|c|}{$8 s 2 p$} & \multicolumn{3}{|c|}{$8 \mathrm{~s} 10 \mathrm{p}$} & \multicolumn{2}{|c|}{$8 \mathrm{~s} 1 \mathrm{p}$} \\
\hline Rp+Ro & $100 \%$ & 39,2 & 65 & & 22 & 26 & 30 & 56 & 5962 \\
\hline Rp+Ro & $\sim 15 \%$ & 82 & 92 & 102 & 37 & 43 & 49 & 94 & 9698 \\
\hline \multicolumn{2}{|c|}{ R_producer } & & 40 & & & 15 & & & 48 \\
\hline
\end{tabular}

Table 3: Internal resistance of a pack: calculated from Table 2

The internal resistance increases with approx. 50\% when the SOC decreases from $100 \%$ to $15 \%$ for both (10Ah and 120A) packs. The internal resistance value on the datasheets is the half of the one from the FreedomCar model. Now it is type 1 which has the lowest internal resistance value because of many parallel placed cells (4 parallel groups of cells, each containing 8 cells in series). Putting so many cells in a pack asks for a good battery management, which is a disadvantage.

\subsection{Influence of resting cells}

Fig. 4, Fig. 5 and Fig. 6 show $\mathrm{R}_{\mathrm{p}}, \mathrm{R}_{\mathrm{o}}$ and OCV' of type 1 as a function of SOC in case when the cells 
have rested for 1 day ("1 day of no load time") and in case when the cells have already done 5 non-stop discharge cycles and have only rested for half an hour ("30min. of no load time").

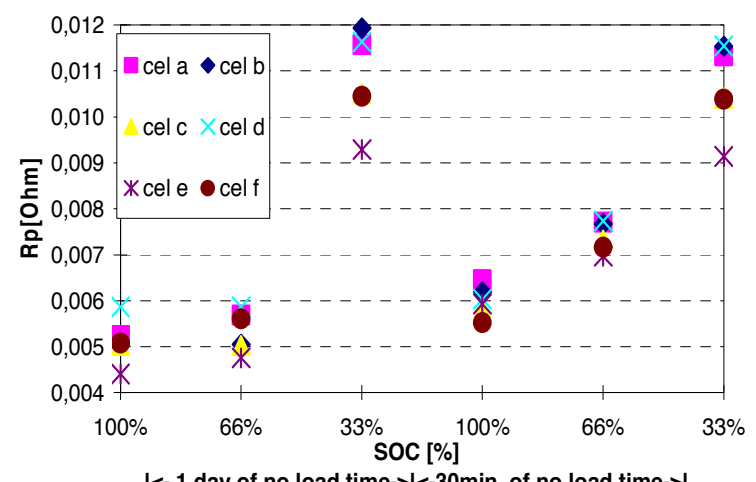

k-1 day of no load time- $>\mid<-30 \mathrm{~min}$. of no load time->1

Fig. 4: $R_{p}=f(S O C)$ : after resting 1day (left) and 30min. (right)

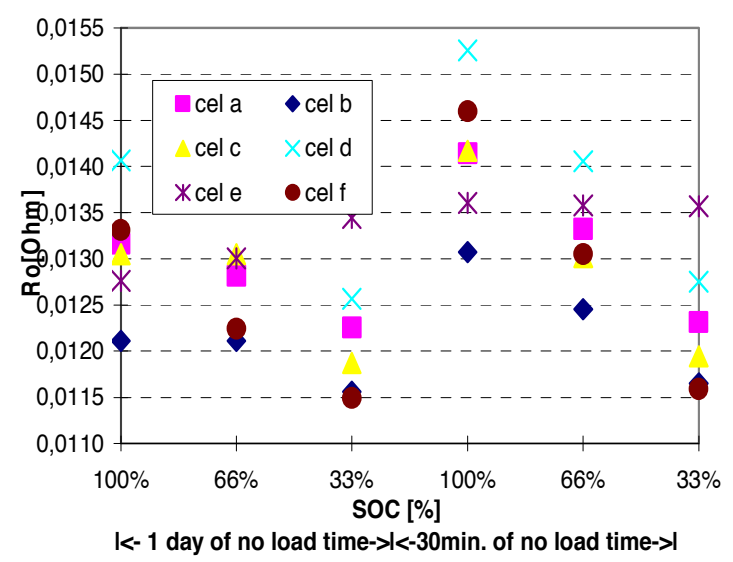

Fig. 5: $R_{o}=f(S O C)$ : rested and less rested

When the parameters are measured before and after 5 discharge cycles, $\mathrm{R}_{\mathrm{p}}$ and $\mathrm{R}_{\mathrm{o}}$ increase with approx. $20 \%$.

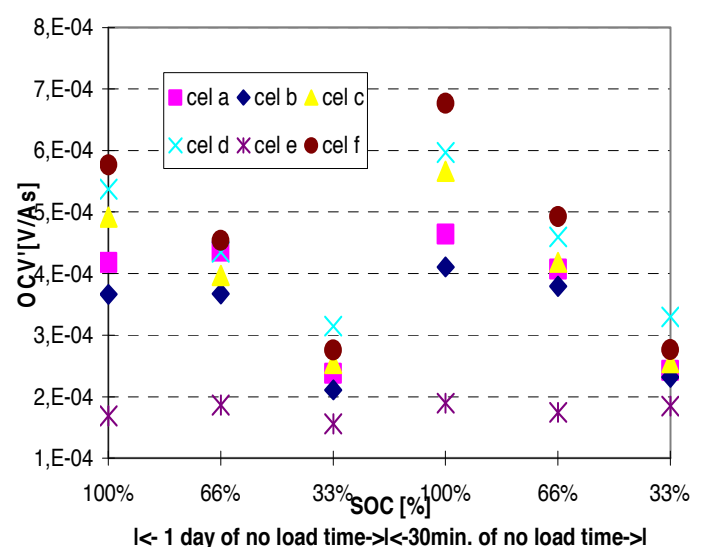

Fig. 6: $O C V^{\prime}=f(S O C)$

OCV' (Fig. 6) is the decrease of the cell voltage per discharged As. It decreases with $40 \%$ when the SOC decreases from $100 \%$ to $33 \%$ and it increases with $15 \%$ in case when the batteries have not rested.

\subsection{Influence of current}

Changing the load profile does increase the internal resistance of a battery, even if the new profile is less heavy than the previous one. Fig. 7 shows $R_{p}$ for type 3 . The FreedomCar tests are done at 120A until 509Ah, also written in red on the figure. From $509 \mathrm{Ah}$ to $556 \mathrm{Ah}$ the tests are done at $60 \mathrm{~A}$. From $556 \mathrm{Ah}$ on the tests are done at 40A.

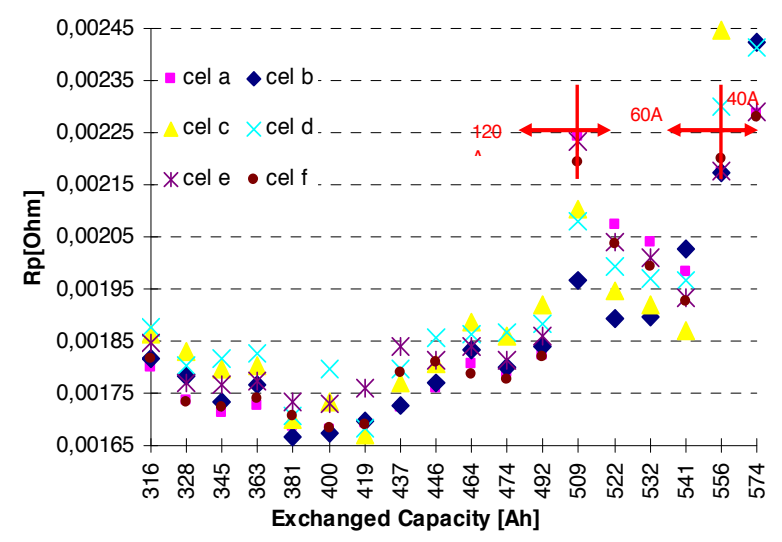

Fig. 7: Rp as a function of the exchanged capacity

When the cycle profile changes for the first time from $120 \mathrm{~A}$ to $60 \mathrm{~A} \mathrm{R}_{\mathrm{p}}$ increases with $25 \%$. But after a few cycles it comes back to the original value. 


\section{Influence on discharge time}

\subsection{Influence of exchanged capacity on discharge time}

When the exchanged capacity increases, the battery can deliver the maximum current for shorter time (Fig. 8).

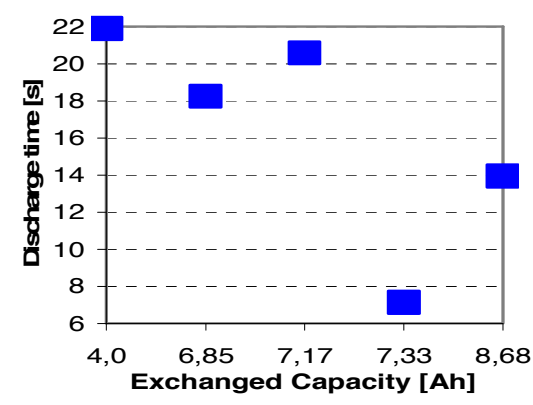

Fig. 8: Discharge time as a function of the exchanged capacity

\subsection{Influence of SOC on discharge time}

When the SOC of the battery decreases, the battery provides the requested current during a shorter time (Fig. 9).

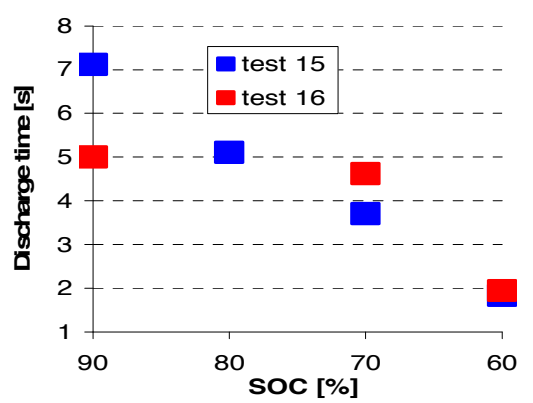

Fig. 9: Discharge time $=f(S O C)$

\section{Temperature and ageing}

The temperature increases with $2^{\circ} \mathrm{C}$ when several tests are done continuously with less pause despite of the fan. This has the same effect as decreasing the SOC: Rp and Ro increases with the increasing temperature.

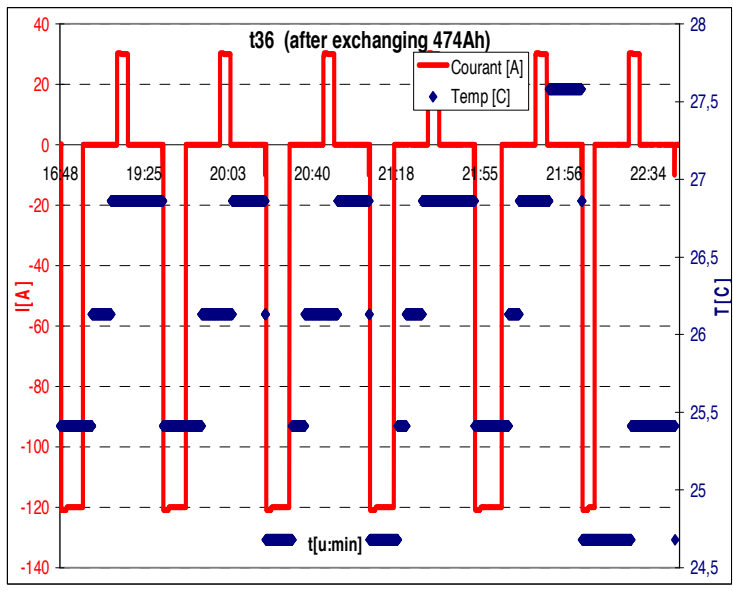

Fig. 10: Temperature $\left[{ }^{\circ} \mathrm{C}\right]$ as a function of time[h:min] for type 3

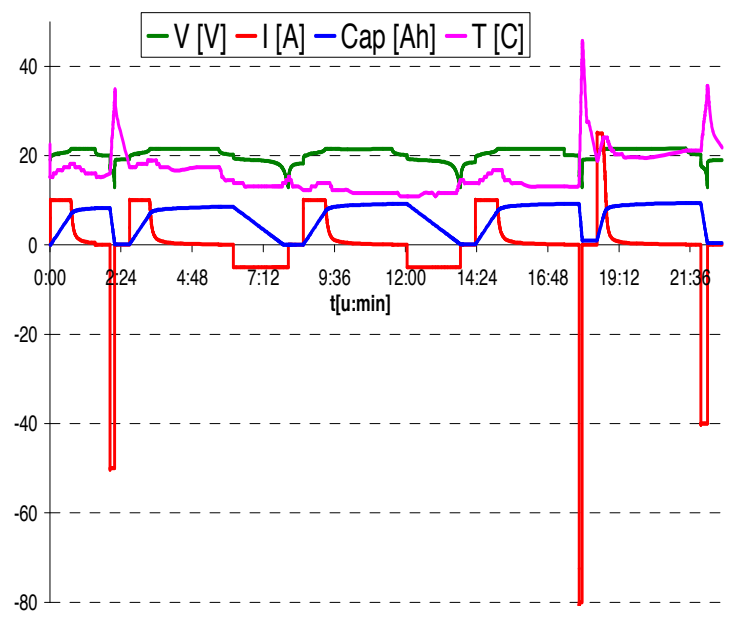

Fig. 11: Temperature $\left[{ }^{\circ} \mathrm{C}\right]$ and capacitye as a function of time $[\mathrm{h}: \mathrm{min}]$ for type 3

Fig. 11 shows that the decrease of the capacity at high discharge currents is not only due to the high current but also due to the high temperature, which increases up to $45^{\circ} \mathrm{C}$ [6]. The fan was not sufficient to cool the battery when it was discharging with $80 \mathrm{~A} \mathrm{CC}$ until he was empty. The temperature increased till $45^{\circ} \mathrm{C}$. No ageing test were performed neither was the influence of temperature analysed at the moments. This will be carried out in future work. But the producer did a ageing test for type 1 (Fig. 12). 


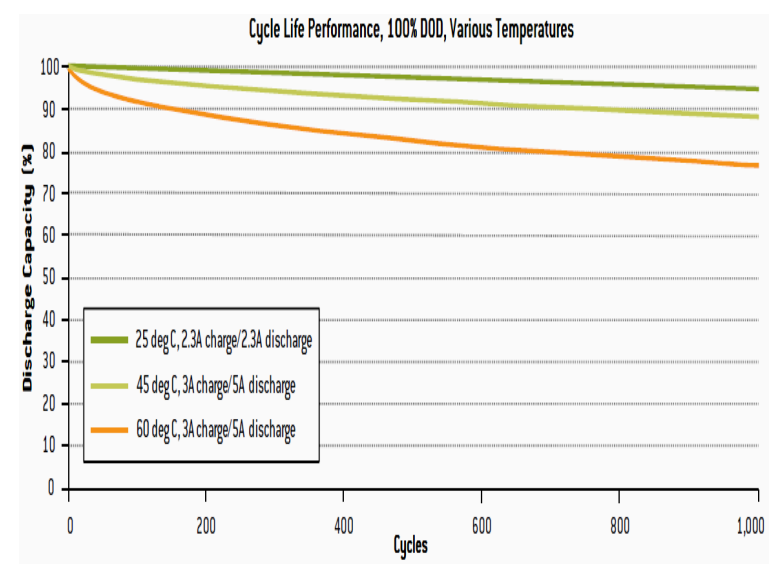

Fig. 12: Ageing test for type 1 cell[6]

\section{Energy and efficiency}

\subsection{Energy}

Fig. 13 show the energy imbalance between the cells for type 3 cells. Cell 5 and 3 got the lowest energy input because of their little higher internal resistance in comparison with other cells. The efficiency of cell 3 and 5 is also low on Fig. 15.

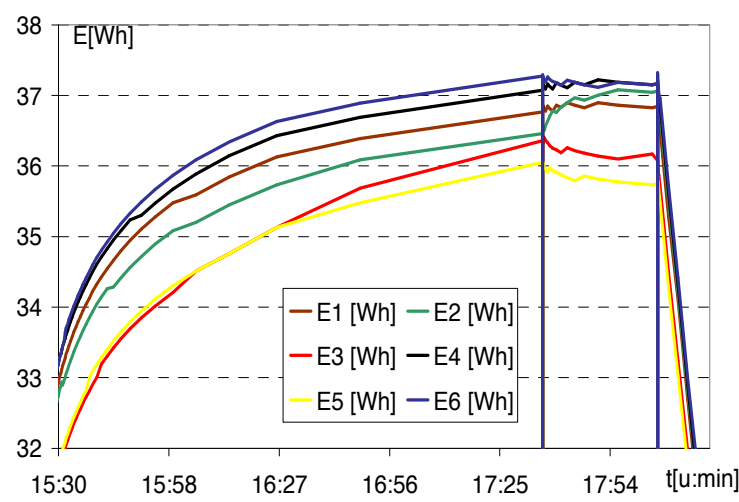

Fig. 13: Energy imbalance between the cells $=f(t)$; $t$ in [h: $\min ]$

\subsection{Efficiency}

Fig. 14 and Fig. 15 show the efficiency of type 1 and type 3 cells.

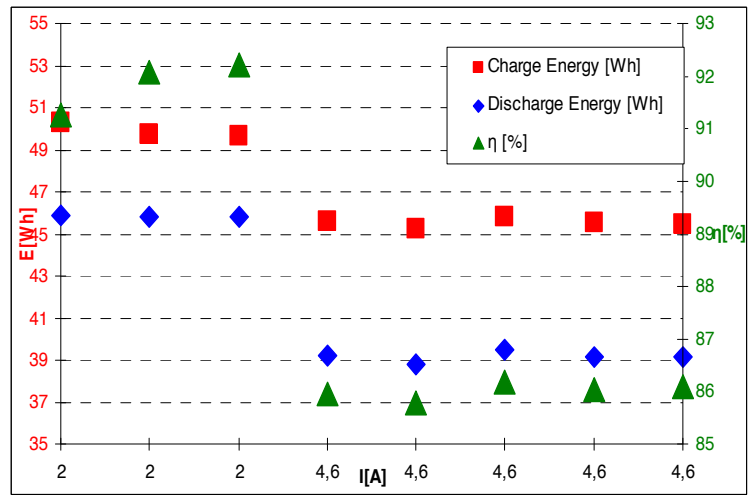

Fig. 14: Charge and discharge energy and efficiency of type 1 cell as a function of current

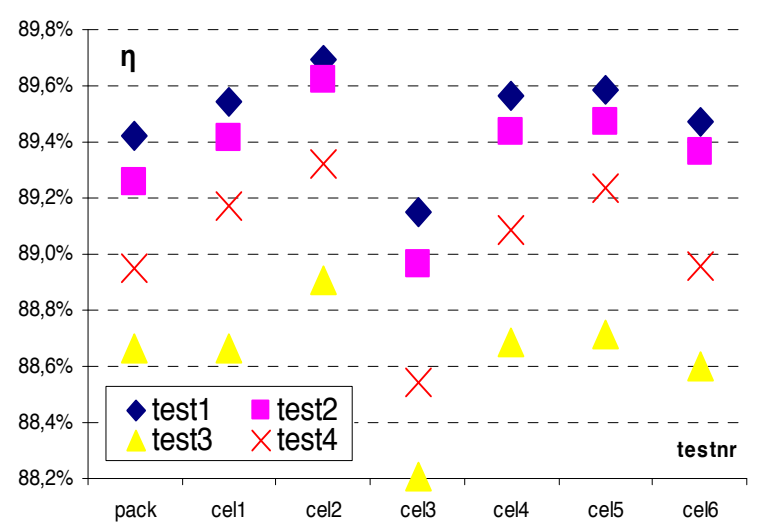

Fig. 15: Efficiency of type 3 cell at 10 A CC discharge

The efficiency of type 3 cell is much higher at reasonable currents.

\subsection{Energy loss}

Energy loss of the considered packs $(\$ 3.5)$ is calculated by their internal resistance from Table 3. The current and the time is taken from the capacity tests.

$E_{\text {loss }}=R_{i} I^{2} t=R_{i} I^{2} \frac{C a p}{I}$

The energy loss due to the internal resistance is between $4 \mathrm{kWs}$ and $33 \mathrm{kWs}$. Type 1 has the lowest loss. The percentages are also calculated, referred to the maximum energy that the packs contain. 


\begin{tabular}{|c|c|c|c|c|c|c|c|c|c|c|}
\hline $\mathrm{E}[\mathrm{kWs}]$ & SOC & \multicolumn{3}{|c|}{ type 1} & \multicolumn{3}{|c|}{ type 2} & \multicolumn{3}{|c|}{ type 3} \\
\hline & [\%] & \multicolumn{3}{|c|}{ min mean max } & \multicolumn{3}{|c|}{ min mean max } & \multicolumn{3}{|c|}{ min mean $\max$} \\
\hline \multicolumn{2}{|c|}{ Pack 24V 10Ah } & \multicolumn{3}{|c|}{$8 \mathrm{~s} 4 \mathrm{p}$} & \multicolumn{3}{|c|}{$8 \mathrm{~s} 3 \mathrm{p}$} & \multicolumn{3}{|c|}{$8 \mathrm{~s}$} \\
\hline E_loss $=R I^{2} t$ & $100 \%$ & 2,9 & 4,8 & 6,7 & 17 & 19 & 22 & 19 & 20 & 21 \\
\hline E_loss[\%] & $100 \%$ & 0,4 & 0,7 & 0,9 & 2,1 & 2,4 & 2,8 & 2,6 & 2,7 & 2,9 \\
\hline E_loss=RI't & $\sim 15 \%$ & 6,0 & 6,7 & 7,4 & 27 & 32 & 36 & 32 & 33 & 34 \\
\hline E_loss [\%] & $\sim 15 \%$ & 0,8 & 0,9 & 1,0 & 3,4 & 3,9 & 4,5 & 4,4 & 4,4 & 4,5 \\
\hline E_loss_prod & & & 0,72 & & & 11 & & & 16 & \\
\hline E_loss [\%] & & & 0,1 & & & 1,4 & & & 2,2 & \\
\hline \multicolumn{2}{|c|}{ Pack 24V 120A } & \multicolumn{3}{|c|}{$8 \mathrm{~s} 2 \mathrm{p}$} & \multicolumn{3}{|c|}{$8 \mathrm{~s} 10 \mathrm{p}$} & \multicolumn{3}{|c|}{$8 \mathrm{~s}$} \\
\hline E_loss $=R I^{2} t$ & $100 \%$ & 0,4 & 0,6 & 0,8 & 0,2 & 0,2 & 0,3 & 0,5 & 0,5 & 0,6 \\
\hline E_loss[\%] & $100 \%$ & 0,3 & 0,5 & 0,8 & 0,2 & 0,2 & 0,3 & 0,5 & 0,5 & 0,5 \\
\hline E_loss $=R I^{2} t$ & $\sim 15 \%$ & 0,4 & 0,6 & 0,8 & 0,2 & 0,2 & 0,3 & 0,5 & 0,5 & 0,6 \\
\hline E_loss[\%] & $\sim 15 \%$ & 0,3 & 0,5 & 0,8 & 0,2 & 0,2 & 0,3 & 0,5 & 0,5 & 0,5 \\
\hline$R_{\_}$producer & & & 0,4 & & & 0,1 & & & 0,4 & \\
\hline E_loss[\%] & & & 0,3 & & & 0,1 & & & 0,4 & \\
\hline
\end{tabular}

Table 4: Energy loss in [kWs] and in [\%] for packs

\section{Capacity}

Fig. 16, Fig. 17 and Fig. 18 show the capacity for the three cell types. They are in the order of what is written on the datasheet, except type 2 . It has a lower capacity than on the datasheet because the cells were charged to $3.55 \mathrm{~V}$ instead of $3.65 \mathrm{~V}$ in order to be safe.

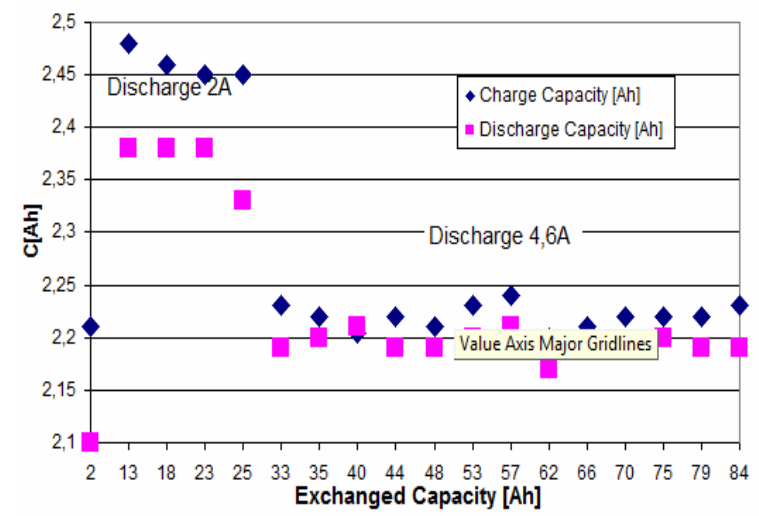

Fig. 16: Capacity of type 1 cell

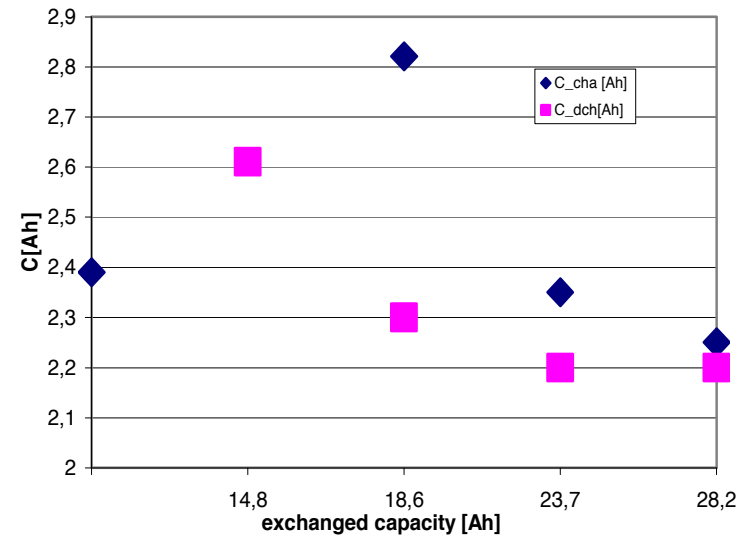

Fig. 17: Capacity of type 2 cell

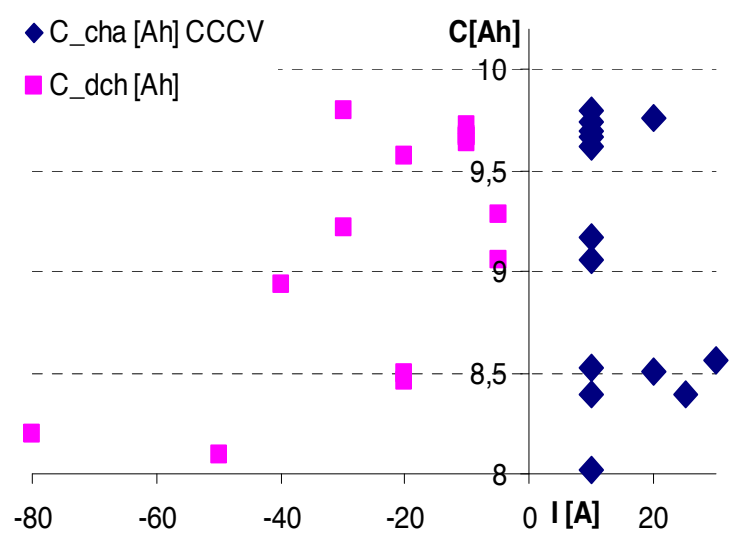

Fig. 18: Charge and discharge capacity of type 3 cell as a function of current

Fig. 18 shows the capacity decrease as a function of the current for type 3 .

\section{Voltage imbalance}

Voltage imbalance between the cells is maximum $0,2 \mathrm{~V}$ (Fig. 19). It decreases when the cells are charged with a low current.

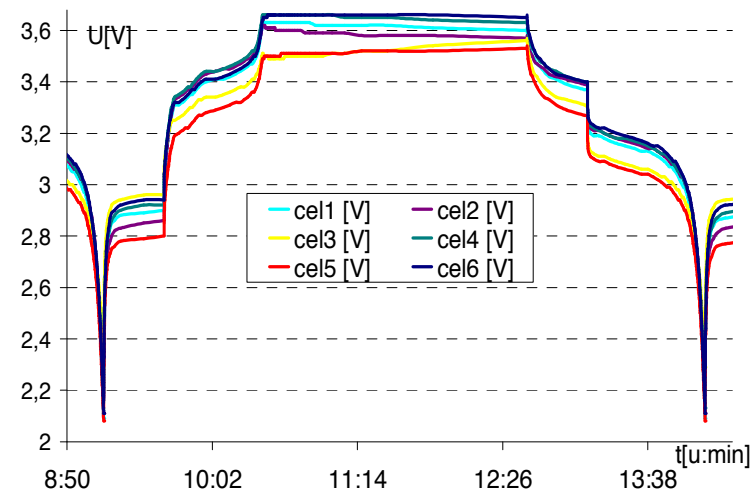

Fig. 19: Cell voltages $=f(t) ; t$ in $[h: \min ]$ 


\section{CONCLUSION}

The internal resistance is $50-100 \%$ higher than the value on the producers' datasheet. Moreover it increases with $50-100 \%$ when the battery gets empty. Furthermore it increases with $20 \%$ when the cells have not rested for long time.

Type 3 cell has the lowest internal resistance and shows also that the producers can provide the realistic value for internal resistance.

The internal resistance imbalance is lowest for type 3 cell. This can be correlated with the voltage imbalance. If the voltage imbalance is low, then there is less need for a battery management or the energy system is less dependent from a battery management system.

Decreasing the load current increases the internal resistance for few cycles. After few cycles the internal resistance drops down to the original value. So it is only the change of the load profile that increases the internal resistance in this case.

The temperature only increases with $2^{\circ} \mathrm{C}$ during one FreedomCar test.

The energy loss is calculated from the internal resistance value.

The efficiency of the cells are around $88 \%$.

\section{REFERENCES}

[1] D. Uwe Sauer (Aachen University, Germany), Simulation and Battery Monitoring, ECPE seminar, june 2007

[2] F. Van Mulders, A basic model for evaluating a direct battery and supercapacitor parallel connection, EET-2008, Mar. 2008, pp3-5

[3] Idaho National Engineering \& Environmental laboratory, FreedomCAR Battery Test Manual For Power-Assist Hybrid Electric Vehicles, Oct. 2003

[4] Idaho National Laboratories (USA), http://avt.inl.gov/energy storage lib.shtml, accessed on $5 / 6 / 2008$

[5] Idaho National Engineering \& Environmental laboratory, Battery Technology Life Verification Test Manual, feb. 2005

[6] A123systems, http://a123systems.com/\#/products/p1, accessed on $15 / 10 / 08$

[7] G-A Nazri, Lithium batteries, KAP, 2004, pp645-684

[8] M. Urbain, Energetical Modelling of Lithium-Ion Battery Discharge and Relaxation, Industry Applications Conference, 2007, pp714-721

[9] W. Waag, Impedance-based monitoring of EDLC, EESCAP, Vol.3, sep. 2008

[10] M. Coleman, State-of-Charge Determination From EMF Voltage estimation: Using Impedance, Terminal Voltage, and current for Lead-Acid and Lithium-Ion Batteries, IEEE: Ind. Electronics, Vol. 54, NO. 5, OCTOBER 2007

[11] H. Culcu, MIPCUB: Combination ultracapacitors with batteries for stationary and not-stationary applications, MIPCUB project (Belgium), may 2008, pp51-93

[12] Idaho National Engineering \& Environmental laboratory, FreedomCAR Battery T-est Manual For Power-Assist Hybrid Electric Vehicles, Oct. 2003

[13] J. Van Mierlo, Simulation software for comparison and design of electric, hybrid electric and internal combustion vehicles with respect to energy, emissions and performances, Ph.D. dissertation, Dept. Elect. Eng, Vrije Universiteit Brussel, Belgium, Apr. 2000

[14] B.D. McNicol, Power Sources for Electric Vehicles, Elsevier, 1984, pp.747-751, 755

[15] J.-M. Tarascon, Issues and challenges facing rechargeable lithium batteries, Macmillan Magazines, 2001, pp359-367

[16] J. Weinert, A. Burke, Lead-acid and Lithium-ion Batteries for the Chinese Electric Bike Market and Implications on Future Technology Advancement, UCDavis, 2007

[17] R.Chandrasekaran, Capacity Fade Analysis of a Battery/Supercapacitor Hybrid and a Battery under pulse loads, University of South Carolina (USA), 2003

[18] Chisato Marumo 'Design and performance of laminated lithium-ion capacitors' JM Energy Corporation Japan, Advanced Capacitor World Summit 2008, July 2008, San Diego USA

[19] Guerin, J. T. and Andrew F. Burke, Load Leveled Battery System Characteristics Using Sealed Lead-Acid Batteries, Proceedings of the 32nd Intersociety Energy Conversion Engineering Conference (IECEC-97) 2, 1997, pp883 - 888

[20] A.F. Burke, Cycle Life Considerations for Batteries in Electric and Hybrid Vehicles. Society of Automotive Engineers Technical Paper Series, 1995

[21] A.F. Burke, A Method for the Analysis of High Power Battery Designs, Institute of Transportation Studies, University of California, Davis CA (USA), 1999

\section{Hasan CULCU}

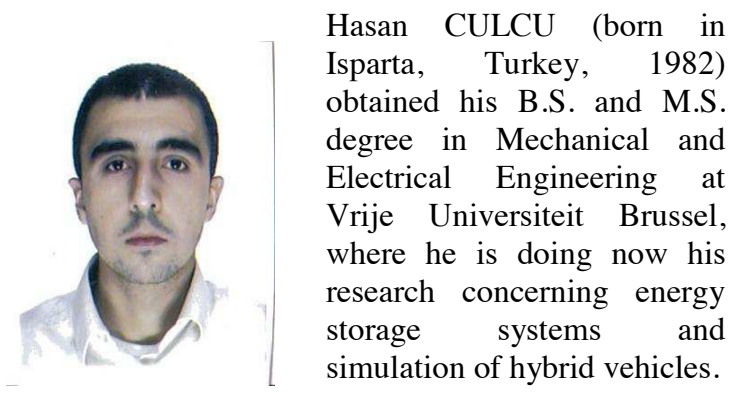

\section{Bavo VERBRUGGE}

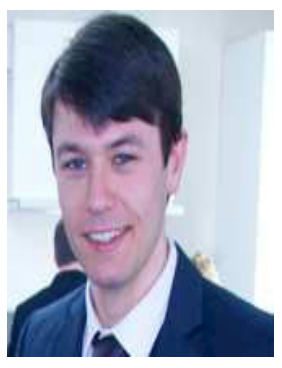

Bavo Verbrugge graduated as a Master degree in industrial engineering in 2007. At this time he works as a PhD. candidate at the free University of Brussels (VUB), where he's currently performing research on integrated modelling of batteries and EDLC's. 


\section{Noshin OMAR}

Noshin Omar was born in Kurdistan, in 1982. He obtained the M.S. degree in Electronics and Mechanics from Hogeschool Erasmus in Brussels. $\mathrm{He}$ is currently pursuing the PHD degree in the department of Electrical Engineering and Energy Technology ETEC, at the Vrije Universiteit Brussel, Belgium. His research interests include applications of supercapacitors and batteries in HEV's.

\section{Peter Van den Bossche}

$\mathrm{He}$ graduated as civil mechanical-electrotechnical engineer from the Vrije Universiteit Brussel and defended his $\mathrm{PhD}$ at the same institution with the thesis

"The Electric Vehicle: raising the standards". $\mathrm{He}$ is currently lecturer at the engineering faculties of the Erasmushogeschool Brussel and the Vrije Universiteit Brussel, and in charge of co-ordinating research and demonstration

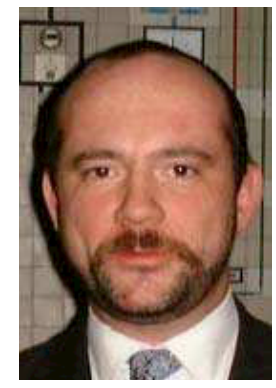

projects for electric vehicles in collaboration with the international associations CITELEC and AVERE. His main research interest is electric vehicle standardization, in which quality he is involved in international standards committees such as IEC TC69, of which he is Secretary, and ISO TC22 SC21.

\section{Joeri Van Mierlo}

Joeri van Mierlo received M.S. and $\mathrm{PhD}$ degree in electromechanical engineering from Vrije Universiteit Brussel in 1992 and 2000 with greatest distinction. From 2004 on he has been appointed as a fulltime professor at the Vrije Universiteit Brussel. Prof. Van Mierlo is head of the MOBI- Mobility and automotive technology research group. Currently his research is devoted to the development of hybrid propulsion (converters, supercaps, energy management, etc.) systems as well as to the environmental comparison of vehicles with different kind of drive trains and fuels. 